\title{
Fra fibroblast til kardiomyocytt
}

\author{
Fibroblaster fra musehjerter kan \\ reprogrammeres til å bli kardio- \\ myocytter in vivo.
}

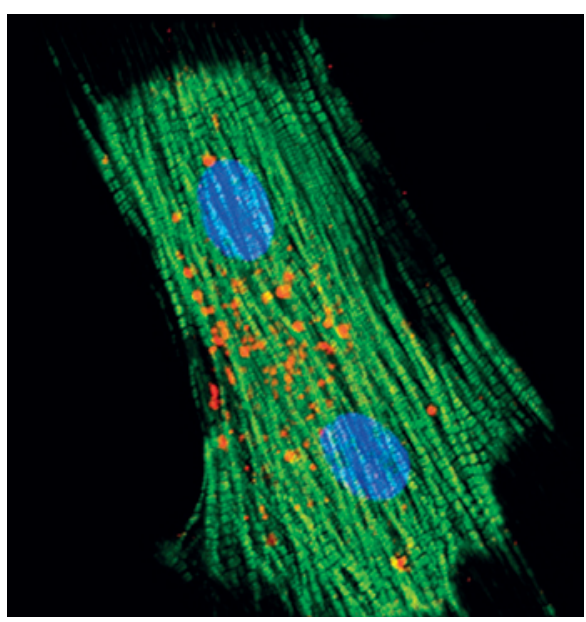

Illustrasjonsfoto Sciencephoto/NTB Scanpix
Kardiomyocytter har ingen evne til å fornye seg. Etter et infarkt svarer hjertet med å danne bindevev fremfor nytt hjertemuskelvev. Celleforsøk har imidlertid vist at en kombinasjon av spesifikke transkripsjonsfaktorer kan reprogrammere fibroblaster fra musehjerte til kardiomyocyttliknende celler. To uavhengige forskergrupper har nå lyktes med en slik reprogrammering in vivo $(1,2)$.

Ved hjelp av retrovirus fikk de uttrykt transkripsjonsfaktorene i hjertet hos mus etter eksperimentelt hjerteinfarkt. Intervensjonen ga nye kardiomyocytter, redusert omfang av infarktet og dermed redusert dysfunksjon av hjertet. De nye fibroblastderiverte kardiomyocyttene viste kontraksjon ved stimulering, aksjonspotensialer og evne til elektrisk kobling typisk for ventrikulære kardiomyocytter.

- Disse studiene ble gjennomført av to velrenommerte forskergrupper uavhengig av hverandre, sier overlege Thomas von Lueder ved Hjertemedisinsk avdeling, Akershus universitetssykehus. - Hovedutfordringen var å vise at de nye hjertecellene i infarktets randsone faktisk var reprogrammerte fibroblaster. Begge grupper viste dette og fikk bedring av hjertefunksjon i samme størrelsesorden, men andelen nye kardiomyocytter var ganske ulik.

Spørsmålet er om de nye kardiomyocyttene styrker pumpekraften eller fører til for eksempel økt blodkardanning eller cellulær overlevelse. Videre forskning vil avklare om det er mulig å få andre hjerteceller enn fibroblaster til å bli reprogrammert, og uten retrovirusbasert endring av arvematerialet, sier von Lueder.

\section{Trine B. Haugen \\ trine.b.haugen@hioa.no \\ Tidsskriftet}

Litteratur

1. Qian L, Huang Y, Spencer $\mathrm{Cl}$ et al. In vivo reprogramming of murine cardiac fibroblasts into induced cardiomyocytes. Nature 2012; 485: 593-8.

2. Song $\mathrm{K}, \mathrm{Nam} \mathrm{YJ}$, Luo $\mathrm{X}$ et al. Heart repair by reprogramming non-myocytes with cardiac transcription factors. Nature 2012; 485: 599-604.

\section{Misdannelser etter assistert befruktning}

\section{Hos barn unnfanget etter assistert befruktning er det høyere risiko for medfødte misdannelser. Årsaken til dette kan være risikofaktorer hos moren.}

Risikoen for misdannelser hos barn unnfanget etter assistert befruktning er nylig undersøkt i en stor kohortstudie fra Australia (1). Alle fødsler og aborter med svangerskapslengde $\geq 20$ uker ble registrert, og opplysninger om misdannelser ble samlet frem til barnet var fem år. Studien omfattet 308974 fødsler. 6163 av disse var resultat av ulike former for assistert befruktning.

Ikke-korrigerte data viste at fødsler etter assistert befruktning var assosiert med økt risiko for misdannelser $(\mathrm{n}=513,8,3 \%)$ sammenliknet med fødsler hos dem som ble spontant gravide $(\mathrm{n}=17546 ; 5,8 \%)$, OR $1,47(95 \%$ KI 1,33-1,62). Etter justering for andre risikofaktorer, f.eks. morens alder, var det kun behandling med intracytoplasmatisk spermieinjeksjon (ICSI) som fortsatt var assosiert med statistisk signifikant økt risiko.

- Dette er en godt gjennomført populasjonsbasert studie med tilnærmet $100 \%$ oppfølging av alle svangerskap etter 20 . svangerskapsuke, sier Tom Tanbo, seksjonsleder og professor ved reproduksjonsmedisinsk seksjon, Oslo universitetssykehus, Rikshospitalet. - Kodingen av utviklingsavvik ble foretatt på en betryggende måte. Det er imidlertid en svakhet ved studien at den ikke inkluderer svangerskap med påviste utviklingsavvik som ble avsluttet før uke 20 .

Studien bekrefter resultatene fra tidligere studier, spesielt store studier fra Skandinavia. Den bekrefter også funn om at tidligere infertilitet i seg selv er assosiert med økt risiko for utviklingsavvik hos barnet, sier Tanbo.

\section{Merete Kile Holtermann}

merete.holtermann@legeforeningen.no

Tidsskriftet

\section{Litteratur}

1. Davies MJ, Moore VM, Willson KJ et al. Reproductive technologies and the risk of birth defects. N Engl J Med 2012; 366: 1803-13.

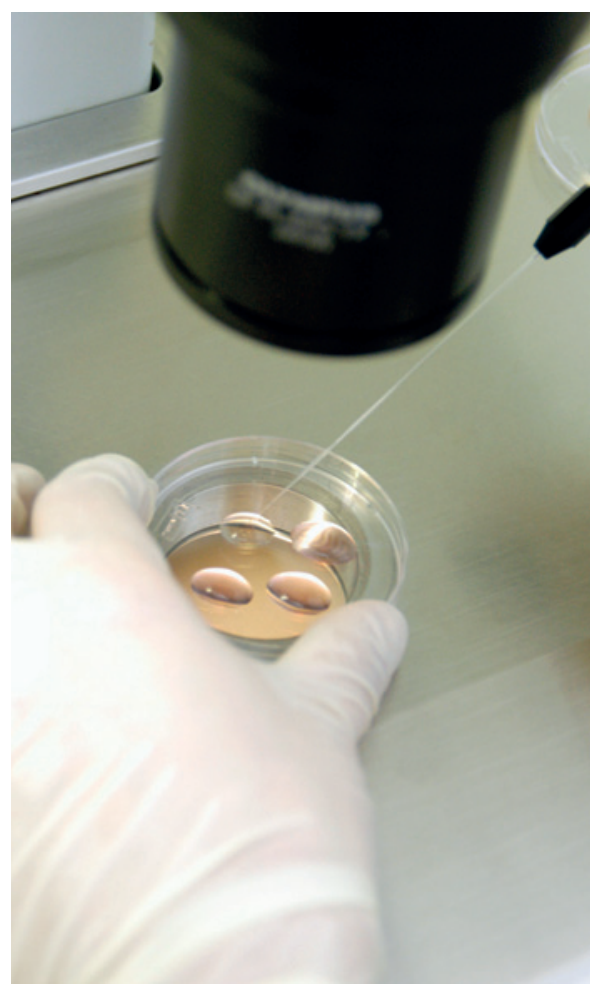

Illustrasjonsfoto Sciencephoto/NTB scanpix 